\title{
Influence of a Small Hydroelectric Power Station on the River Ecosystem.
}

\author{
Enrique Valero ${ }^{1}$, Xana Álvarez ${ }^{1 *}$, Juan $\operatorname{Picos}^{1}$
}

\begin{abstract}
:
To assess the effects of the Small Hydroelectric Power Station (SHP) on the fluvial ecosystem, some environmental values are required to measure. This work provides a characterization of the water quality status in a river stretch around a SHP plant on river Mandeo, (NW Spain), for three years after its construction. The ecological and chemical status of the water and the ecological quality of the riparian habitat was analyzed and comparing with the water quality requirements. The results showed that there were not significant differences between sampling points (before and after of the plant), as well as a stabilization of the parameters within two years after the construction of the Station, achieving conditions ecologically compatible. We concluded that the construction of the SHP plant caused an adverse effect in the ecosystem, which was subsequently improved. Highly positive results from the point of view of their contribution as a source of renewable energy.
\end{abstract}

Keywords: Biological index, physicochemical, SHP plant, riparian forest quality index

\section{Introduction}

Renewable energy technologies are one of the most important solutions to the problematic dependence on fossil fuels (Míguez et al., 2006) and the environmental problems (Dincer, 2000) that this entails.

Among these energies, green power is the electricity generated from wind, solar, small hydro, geothermal and biomass sources (Islam et al., 2004). The energy generated from wind show as use a resource inexhaustible in benefice of persons, however we know that no is available for all places, previously is necessary a complete area studio. Also sunlight is employee for supply many needs and it's available in largely of places, with this green energy can cook, have drinking water, warm water and produce electric current, this is a very important, especially in areas where poverty is the protagonist and this form they can thrive gently. In particular, hydropower provides about $17 \%$ of EU electricity supply (Paish, 2002), it is the most traditional clean renewable energy source and the most important for electrical power production worldwide.

SHP is one of the most cost-effective renewable energy technology with a high capacity utilization factor (Paish, 2002). Despite the environmental benefits of the SHP, some ecological values are still threatened by this form of renewable energy. SHP plants are

AF4 Research Group. Engineering Department of Natural Resources and Environment, Forestry. Engineering College, University of Vigo, Campus a Xunqueira s/n, 36005

Pontevedra, Spain.

* Corresponding author. 
located in such important stream ecosystems, generally in areas of high ecological value (Valero, 2012).

The aim of this research is to describe the quality of the riverine ecosystem on a river stretch which includes a SHP plant, on river Mandeo, Galicia (Spain). The ecological and physicochemical status of the stream water, as well as the ecological quality of the riparian vegetation was used as measures of quality. For this aim, the variations existing in the quality parameters were analyzed according to the location of the sampling points with respect to the plant elements, and throughout the time since the plant installation.

\section{Material and Methods}

a. Study Area

The Gomil SHP station is situated in the Mandeo river, in Galicia. The climate in the area is oceanic: the average annual rainfall is between $1246 \mathrm{~mm}$ and the average temperature is $14.8^{\circ} \mathrm{C}$ (Martínez Cortizas and Pérez, 2000; Carballeira et al., 1983).

Mandeo river belongs to the Atlantic watershed of Galicia. The flow regime of the water flows in Galicia is related with the rainfall distribution (Martínez and Membiela, 1992). The periods of highest flow is between December and March, and minimum occurs in September. In the natural vegetation in the riversides we can find oak (Quercus robur), black alder (Alnus glutinosa), willow (Salix atrocinerea), hazel tree (Corylus avellana), elder (Sambucus nigra) and ash (Fraxinus sp.).

The Mandeo stream has been classified as salmonid waters (Ministerio de Medio Ambiente, 2004), i.e., waters which support or become capable of supporting fish belonging to species such as salmon (Salmo salar), trout (Salmo trutta), or other species in other areas of Europe (Directive 2006/44/EC).

\section{b. Sampling and Methodology}

In order to measure the physicochemical parameters of the water, 3 sampling points have been selected in places where the entry does not entail risk and trying to select areas accessible in the future in spite of changes in the flow. The position of the sampling points (Table 1) was registered with a GPS GPSMAP 60CSx (Garmin, Olathe, KS, USA).

The following physicochemical parameters were measured: water temperature $\left({ }^{\circ} \mathrm{C}\right)$, conductivity $(\mathrm{mS} / \mathrm{cm})$, dissolved oxygen $(\mathrm{DO}, \mathrm{mg} / \mathrm{L})$, and $\mathrm{pH}$, using a handheld multiparameter instrument YSI 556MPS (YSI, Yellow Springs, OH, USA).

The biological quality of the water was assessed using the index Iberian Biological Monitoring Working Party IBMWP (Alba-Tercedor and Sánchez-Ortega, 1998; AlbaTercedor et al., 2002). The QBR index was calculated following the protocol (Munné et al., 2003) with some modifications according with Valero et al. (2014). River stretch of $400 \mathrm{~m}$ around the dam, and another river stretch of $650 \mathrm{~m}$ around the SHP station and tail race were selected. 
Table 1 Location of the sampling points and samples taken.

\begin{tabular}{|c|c|c|c|}
\hline $\begin{array}{l}\text { Sampling } \\
\text { points }\end{array}$ & Location & UTM & Sampling \\
\hline 1 & $\begin{array}{l}\text { Upstream the } \\
\text { dam }\end{array}$ & $\begin{array}{l}X=580.041 ; Y= \\
4.782 .033\end{array}$ & $\begin{array}{l}\text { Physicochemical parameters } \\
\text { Biological index (stream section) }\end{array}$ \\
\hline 2 & $\begin{array}{l}\text { Upstream the } \\
\text { tailrace }\end{array}$ & $X=580.333 ; Y=4.786 .222$ & $\begin{array}{l}\text { Physicochemical parameters } \\
\text { Biological index (stream section) }\end{array}$ \\
\hline 3 & $\begin{array}{l}\text { Downstream the } \\
\text { tailrace }\end{array}$ & $\begin{array}{l}50 \mathrm{~m} \text { downstream of the } \\
\text { SHP }\end{array}$ & $\begin{array}{l}\text { Physicochemical parameters } \\
\text { Biological index (stream section) }\end{array}$ \\
\hline
\end{tabular}

These reaches were divided in sections with similar characteristics and we calculated QBR index for each one. Points between two sections with different QBR were located with GPS. The authors of the index established that both river banks should be considered together. Nevertheless, since some SHP plant elements only affect one bank, we calculate one QBR index for each bank.

During the 36 month period between December 2006 and December 2010, all the points were sampled every 3 months for the physicochemical and biological water quality, as well as riparian forest.

\section{Results and Conclusions}

\section{a. Physicochemical Characteristics of the Water}

To analyze the results, we focused on the changes that came before and after the return flow, (points 2 and 3), taking as reference the values of point 1.

The differences between the temperatures recorded between points (2 and 3) are minimal during the samplings in the Mandeo River. As illustrated in Figure 1, the values describe a regular pattern with minor differences. Water temperature variations were seasonal; they were directly related with meteorological conditions.

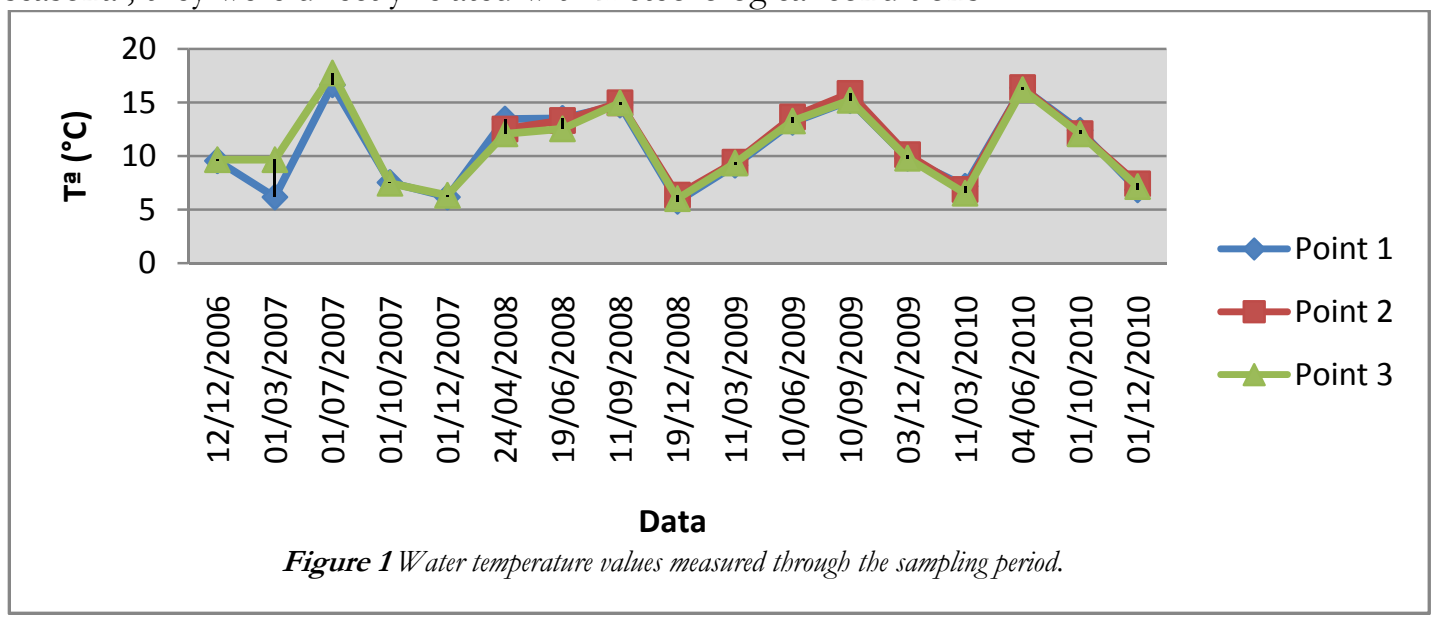


These values were in the expected normal values and they did not vary among the points of analysis. Therefore, it can be concluded that Gomil dam did not affect in the water temperature of the river Mandeo.

The dissolved oxygen in the water is within the normal range according to 2006/44/EC. This law states that at least $50 \%$ of the samples must have a value equal to or greater than $9 \mathrm{mg} / \mathrm{l}$, and the minimum value is $6 \mathrm{mg} / \mathrm{l}$. Both conditions were fulfilled at all points of our study.

Water quality in points studied is good according to the physicochemical parameters. Therefore, the river water is able to support life. In addition to being drinking water, not having problems in groundwater infiltration or generating a deep pollution. The physical and chemical quality of the water is within the range of normal values for the parameters studied. Particularly, if we compare the results of 2010 with 2008 and 2009, there was a tendency to stabilize the $\mathrm{pH}$ values between points 2 and 3 (Figure 2). Proof of this is seen in point 3 , which had very different values in previous analysis, and since the beginning of 2009 it held constant around the value of 6 (Figure 2).

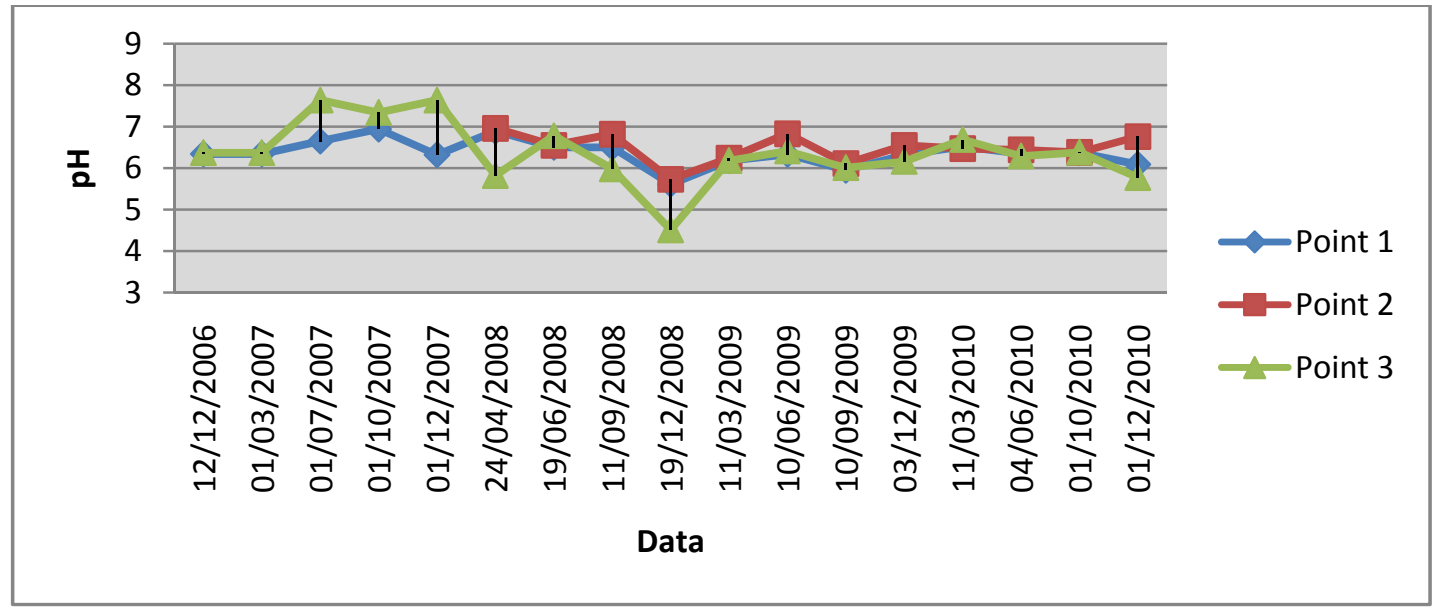

Figure $2 \mathrm{pH}$ values measured through the survey period.

\section{b. Biological Status of the Water}

During 2010, as shown in points 1 and 3 there were not signs of disturbances on the environment. Highlight the point 2 (2009), which had a decrease of the biological quality (Figure 2), keeping this point within the classification of "unpolluted water" according to IBMWP Index. Therefore, there were not significant differences in the IBMWP index between the different points of the dam, particularly between upstream (point 1) and downstream (points 2 and 3). 


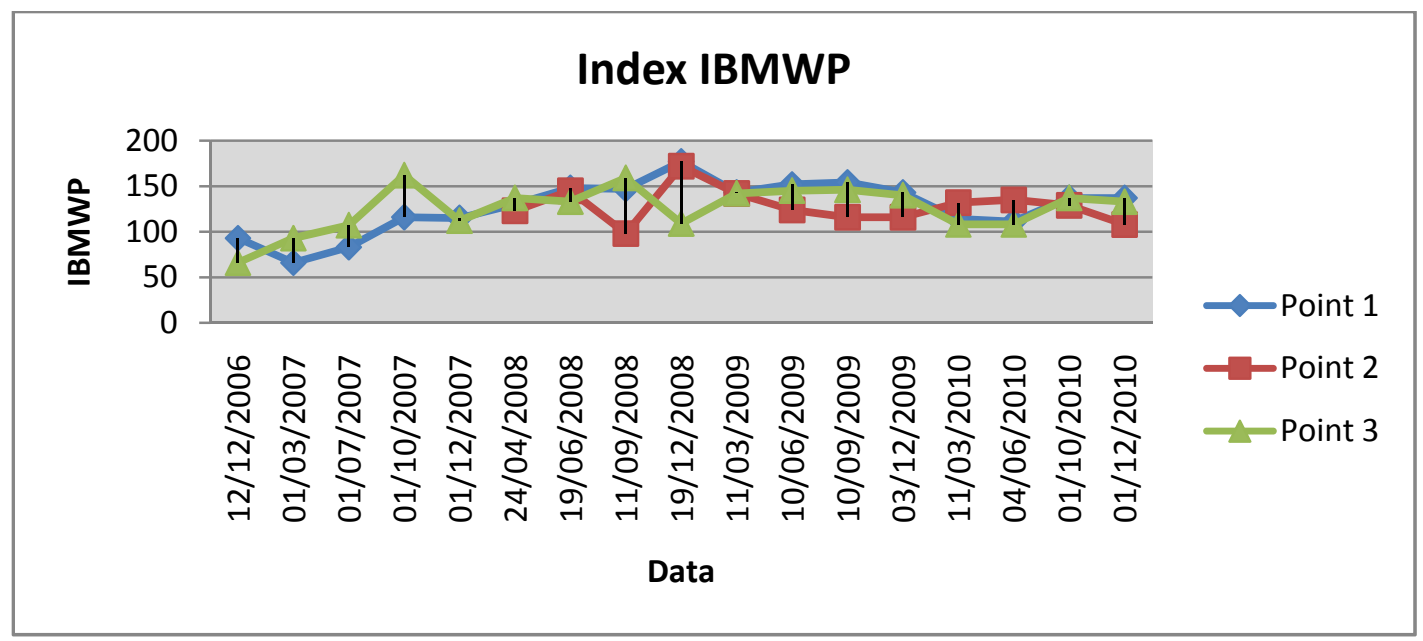

Figure 3 Evolution of IBMWP index during the period of study.

\section{c. Ecological Status of the Riparian Zones}

To estimate the quality and condition of the riparian forest the QBR index has been chosen. QBR index develops a methodology that integrates biological and morphological aspects of the river and its floodplain and this is used to assess the vegetation. Another of the advantages is that its application meets the requirements specified thereon for preliminary characterization cited in Annex V of the WFD. The evaluation of the riparian habitat showed two river bank sections with good status $(\mathrm{QBR} \leq 95)$. Around the power house we observed a river stretch on both river banks, with alterations from extreme degradation. In the remaining sections the riparian habitat was classified as good quality $(\mathrm{QBR}=75-90)$. SHP plant effect on riparian habitat was only observed in the sections affected by the constructions, totalling a stretch of $300 \mathrm{~m}$.

Taking into account the problems affecting our study area, it is necessary to carry out actions to restore riparian forest and to counteract the negative effects of deterioration. The phenomenon that most affects the study area is the strong pressure of agro-livestock activities and roads.

\section{Conclusions}

After a complete analysis of physico-chemical and biological quality, we conclude that the SHP plant not influences significantly in the river ecosystem and habitats that living in it. Our results suggest that SHP plant construction momentarily disturbed the physical-chemical characteristics of the water. As the years go by the construction of the plant, the values have been stabilized. Some measures which could minimize the existing adverse environmental impacts are: decrease of land excavations and blasting during construction, assurance of maintaining minimal river flow downstream of the dam according to relevant legislation. 


\section{Acknowledgments}

This work was possible thanks to the projects developed by the group AF4 for the company TASGA Renovables. Roberto Pérez Lodos and Juan Jesus Berzosa Aránguez from TASGA facilitated the work.

\section{References}

Alba-Tercedor, J. and Sánchez-Ortega, A. (1988), A simple and quick method to evaluate the biological quality of running freshwater based on Hellawell (in Spanish). Limnética , 4, 51-56.

Alba-Tercedor, J.; Jáimez-Cuéllar, P.; Álvarez, M.; Avilés, J.; Bonada, N.; Casas, J.; Mellado, A.; Ortega, M.; Pardo, I.; Prat, N. (2002), Characterization of the ecological status of the Iberian Mediterranean rivers using the index IBWP (former BMWP') (in Spanish). Limnetica , 21,175-185.

Carballeira, A.; Devesa, C.; Retuerto, R.; Santillán, E.; Ucieda, F. Bioclimatology of Galicia (in Spanish); Fundación Pedro Barrie de la Maza: Vigo, Spain, 1983.

Dincer, I. (2000), Renewable energy and sustainable development: A crucial review. Renew. Sustain. Energy Rev. 4, 157-175.

Directive 2006/44/EC of the European Parliament and of the Council of 6 September 2006 on the Quality of Fresh Waters Needing Protection or Improvement in Order to Support Fish Life; Official Journal of the European Communities: Brussel, Belgium, 2006.

Figures about Galicia: Population, Population Centers and Density (in Spanish); Instituto Galego de Estadística: Santiago de Compostela, Spain, 2010. Available online: http://www.ige.eu/igebdt/selector.jsp?COD $=4705 \&$ paxina $=001 \& \mathrm{c}=0501$ (accessed on 23 February 2012).

Islam, M.; Fartaj, A.; Ting, D.S.K. (2004), Current utilization and future prospects of emerging renewable energy applications in Canada. Renew. Sustain. Energy Rev. 8, 493-519.

Paish, O. (2002), Small hydro power: Technology and current status. Renew. Sustain. Energy Rev. 6, 537556.

Martínez Cortizas, A.; Pérez Alberti, A. Climate Atlas of Galicia (in Spanish); Xunta de Galicia, Consellería de Medio Ambiente: Santiago de Compostela, Spain, 2000.

Martínez-Ansemil, E.; Membiela, P. The low mineralized and fast turnover watercourses of galicia.Limnetica 1992, 8, 125-130.

Míguez, J.L.; López-Gonzalez, L.M.; Sala, J.M.; Porteiro, J.; Granada, E.; Morán, J.C.; Juárez, M.C. (2006), Review of compliance with EU-2010 targets on renewable energy in Galicia (Spain). Renew. Sustain. Energy Rev. 10, 225-247.

Ministerio de Medio Ambiente. Manual of the Directive 78/659/CEE on the Quality of Fresh Waters Needing Protection or Improvement to Be Suitable for the Life of Fish (in Spanish); Ministerio de Medio Ambiente: Madrid, Spain, $2004 . \quad$ Available online: http://www.magrama.gob.es/es/agua/publicaciones/02_manual_directiva_78_659_cee_t cm7-28958.pdf (accessed on 1 February 2012).

Munné, A.; Prat, N.; Solà, C.; Bonada, N.; Rieradevall, M. A simple field method for assessing the ecological quality of riparian habitat in rivers and streams: QBR index. Aquat. Conserv. Mar. Freshw. Ecosyst. 2003, 13, 147-163, doi:10.1002/aqc.529.

Valero, E., Picos, J., \& Álvarez, X. (2014). Characterization of riparian forest quality of the Umia River for a proposed restoration. Ecological Engineering, 67, 216-222.

Valero, E. (2012). Characterization of the Water Quality Status on a Stretch of River Lérez around a Small Hydroelectric Power Station. Water, 4(4), 815-834. 